Prepared for the National Nuclear Security Administration,

Office of Defense Nuclear Nonproliferation and

Office of Nonproliferation Research and Development

under U.S. Department of Energy Contract DE-AC05-76RL01830

\title{
Selected Isotopes for Optimized Fuel Assembly Tags
}

\author{
DC Gerlach \\ MR Mitchell \\ BD Reid
}

\author{
CJ Gesh \\ DE Hurley
}

October 2008

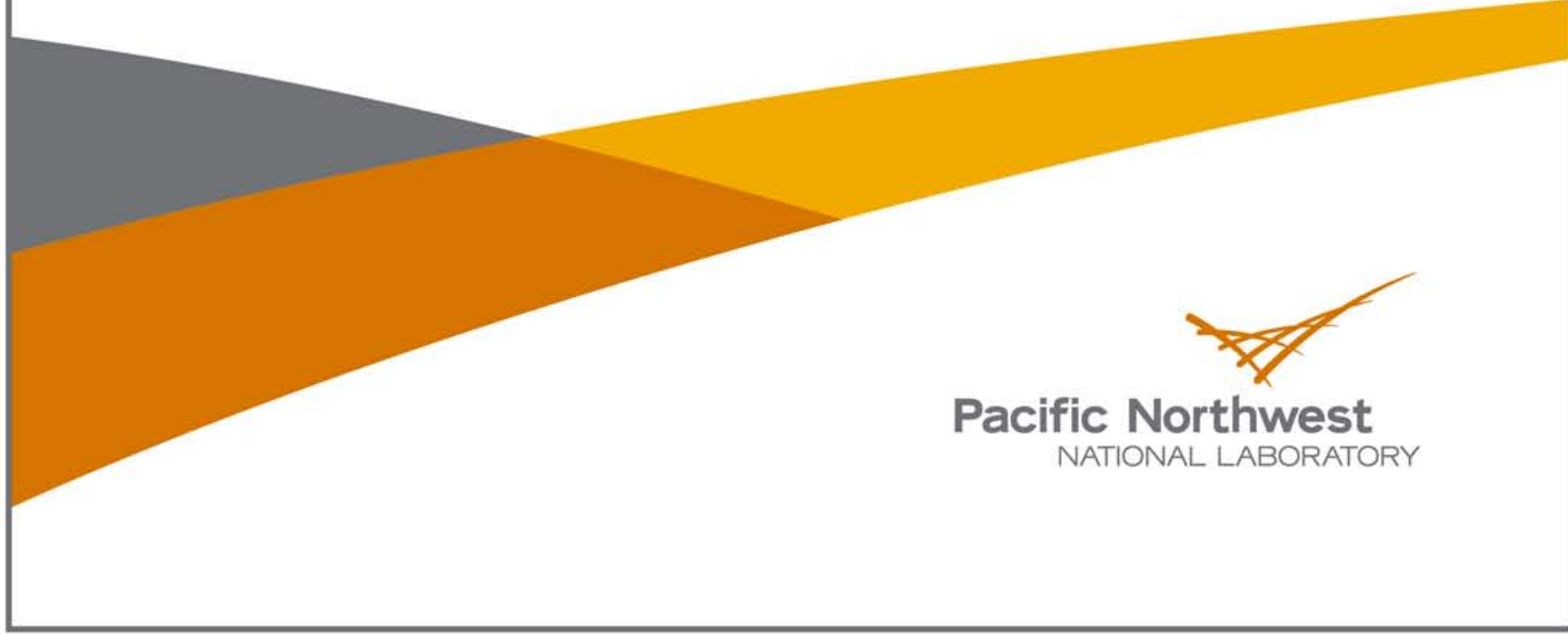




\title{
DISCLAIMER
}

This report was prepared as an account of work sponsored by an agency of the United States Government. Neither the United States Government nor any agency thereof, nor Battelle Memorial Institute, nor any of their employees, makes any warranty, express or implied, or assumes any legal liability or responsibility for the accuracy, completeness, or usefulness of any information, apparatus, product, or process disclosed, or represents that its use would not infringe privately owned rights. Reference herein to any specific commercial product, process, or service by trade name, trademark, manufacturer, or otherwise does not necessarily constitute or imply its endorsement, recommendation, or favoring by the United States Government or any agency thereof, or Battelle Memorial Institute. The views and opinions of authors expressed herein do not necessarily state or reflect those of the United States Government or any agency thereof.

\author{
PACIFIC NORTHWEST NATIONAL LABORATORY \\ operated by \\ BATTELLE \\ for the \\ UNITED STATES DEPARTMENT OF ENERGY \\ under Contract DE-AC05-76RL01830
}

Printed in the United States of America
Available to DOE and DOE contractors from the Office of Scientific and Technical Information,
P.O. Box 62, Oak Ridge, TN 37831-0062;
ph: (865) 576-8401
fax: $(865)$ 576-5728
email: reports@adonis.osti.gov

\begin{abstract}
Available to the public from the National Technical Information Service, U.S. Department of Commerce, 5285 Port Royal Rd., Springfield, VA 22161 ph: (800) 553-6847 fax: $(703) 605-6900$ email: orders@ntis.fedworld.gov online ordering: http://www.ntis.gov/ordering.htm
\end{abstract}

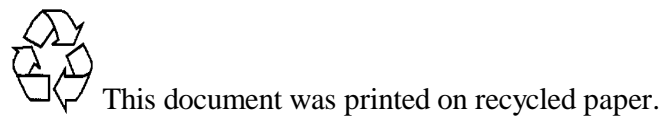




\title{
Selected Isotopes for Optimized Fuel Assembly Tags
}

\author{
DC Gerlach \\ CJ Gesh \\ MR Mitchell \\ DE Hurley \\ BD Reid
}

October 2008

Prepared for the National Nuclear Security Administration, Office of Defense Nuclear Nonproliferation and Office of Nonproliferation Research and Development under U.S. Department of Energy Contract DE-AC05-76RL01830

Pacific Northwest National Laboratory

Richland, Washington 99352 



\section{Summary}

In support of our ongoing signatures project, we present information on three isotopes selected for possible use in optimized tags that could be applied to fuel assemblies to provide an objective measure of burnup.

1. Important factors for an optimized tag are compatibility with the reactor environment (corrosion resistance), low radioactive activation, at least two stable isotopes, a moderate neutron absorption cross section, which gives significant changes in isotope ratios over typical fuel assembly irradiation levels, and ease of measurement in the secondary ionization mass spectrometer.

2. From the candidate isotopes presented in the third FY 2008 quarterly report, the most promising appear to be titanium, hafnium, and platinum. The other candidate isotopes (iron and tungsten) exhibited inadequate corrosion resistance or had neutron capture cross sections either too high or too low for the burnup range of interest.

This report also presents preliminary mechanical design parameters. The most promising mechanical configuration considered so far is a wire or thin ribbon of metal, placed either inside an unused guide or instrumentation tube, or in a groove, machined specifically to accommodate the metal tag, on the outside of these tubes. 



\section{Acronyms and Abbreviations}

$\begin{array}{ll}\text { BWR } & \text { boiling water reactor } \\ \text { Hf } & \text { hafnium } \\ \text { IRM } & \text { isotope ratio method } \\ \text { PNNL } & \text { Pacific Northwest National Laboratory } \\ \text { Pt } & \text { platinum } \\ \text { PWR } & \text { pressurized water reactor } \\ \text { SIMS } & \text { secondary ionization mass spectrometry } \\ \text { Ti } & \text { titanium } \\ \text { VVER } & \text { Russian version of a PWR; Russian abbreviation }\end{array}$





\section{Contents}

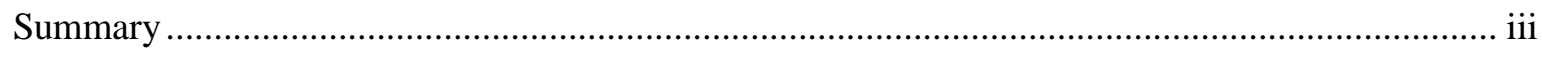

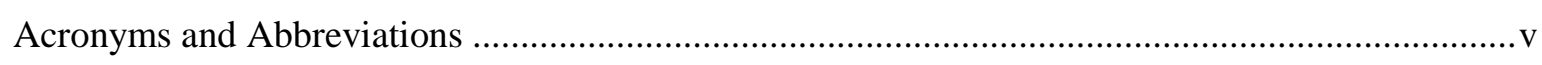

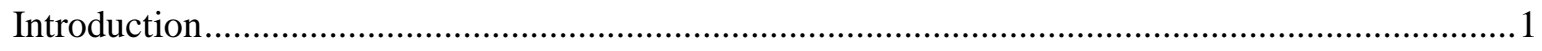

Candidate Elements and Isotopes and Selection of Optimal Tag Materials ..................................2

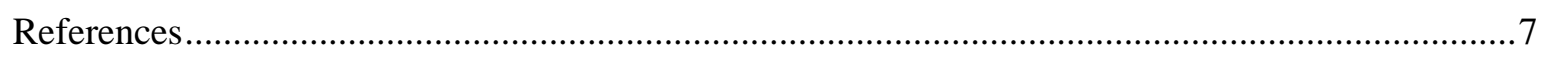

\section{Figures}

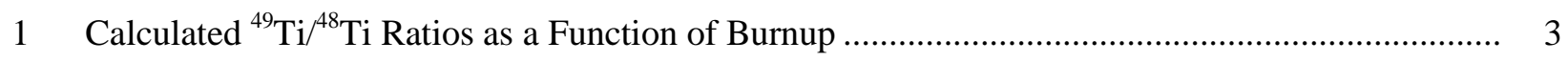

2 Calculated ${ }^{174} \mathrm{Hf} /{ }^{176} \mathrm{Hf}$ Ratios as a Function of Burnup .......................................................... 3

3 Calculated ${ }^{177} \mathrm{Hf}^{176} \mathrm{Hf}$ Ratios as a Function of Burnup......................................................... 4

4 Calculated ${ }^{178} \mathrm{Hf} /{ }^{176} \mathrm{Hf}$ Ratios as a Function of Burnup ........................................................... 4

5 Calculated ${ }^{179} \mathrm{Hf} /{ }^{176} \mathrm{Hf}$ Ratios as a Function of Burnup ............................................................... 5

6 Calculated ${ }^{180} \mathrm{Hf} /{ }^{176} \mathrm{Hf}$ Ratios as a Function of Burnup .............................................................. 5

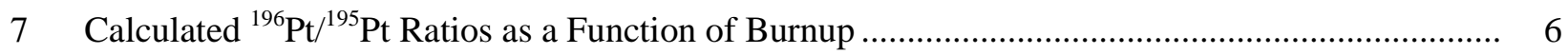

\section{Table}

1 Candidate Elements and Isotopes for Optimized Tags ........................................................ 2 



\section{Introduction}

This report describes the selection process for three isotopes that could be applied to optimized tags that can be applied to standard fuel assemblies used in light water reactors. This report describes work performed by the authors at Pacific Northwest National Laboratory for NA-22 as part of research to identify specific signatures that can be developed to support counter-proliferation technologies.

Isotope ratio methods have been used to estimate total lifetime fluence at research reactors by measuring impurities in aluminum core supports (Cliff et al. 2005) and by measuring impurities in graphite from graphite moderated reactors (Reid et al. 2001; Gesh 2004). One technique for measuring the relative abundance of two isotopes is the secondary ionization mass spectrometer (SIMS). It is particularly well adapted for atomic masses around 50 (Gerlach et al. 2006).

The isotope ratio method (IRM) estimates the energy production in a fission reactor by measuring isotope ratios in non-fuel reactor components. The isotope ratios in these components then can be related directly to the cumulative energy production with standard reactor calculations. Gerlach et al. (2006) discussed using impurities in the Zircaloy components of fuel assemblies, including measurements of samples taken from the fuel assembly channels of commercial boiling water reactors (BWRs)(Gerlach et al. 2007).

Measuring the change in the concentration of a specific isotope is possible; it is difficult to correlate to energy production because the initial concentration of that element may not be known. However, if the ratio of two isotopes of the same element can be measured, the energy production then can be determined without knowledge of the absolute concentration of that impurity because the initial natural ratio is known. This is the fundamental principle underlying the IRM. Extremely sensitive mass-spectrometric methods currently are available that allow accurate measurements of the isotope ratios in a tag.

Rather than rely on trace impurities, the optimized tag approach involves attaching a small tag or chip made of specific isotopes that have desirable nuclear, chemical, and ionization characteristics. One necessary nuclear characteristic is having at least two stable isotopes for isotope ratio measurements. Optimal isotopes have a thermal neutron capture crosssection low enough that they are not practically depleted during anticipated fuel assembly irradiation, have good corrosion resistance and chemical compatibility with the fuel assembly Zircaloy and coolant, and have atomic weights significantly higher or lower than major interference species in the secondary ionization mass spectrometry (SIMS) machine.

Isotope ratio techniques have been demonstrated on titanium and hafnium impurities in commercial Zircaloy. Given enough time and a full-scale SIMS machine, they easily can identify any assembly that was "short-cycled" to produce plutonium as opposed to a full cycle for energy production. However, the optimized tags should enable shorter measurement times and/or the use of miniaturized SIMS machines for analysis at the reactor site. 


\section{Candidate Elements and Isotopes and Selection of Optimal Tag Materials}

In Table 1, the candidate elements and isotopes considered in the study are listed. Candidates selected had at least two stable isotopes and produced significant amounts of radioactive isotopes.

Table 1. Candidate Elements and Isotopes for Optimized Tags

\begin{tabular}{|c|c|c|c|c|}
\hline Element & Stable Isotopes & $\begin{array}{c}\text { Best } \\
\text { Measurable } \\
\text { Ratio(s) }\end{array}$ & $\mathrm{R}(0) / \mathrm{R}(60 \mathrm{GWd} / \mathrm{MT})^{(\mathrm{a})}$ & Corrosion Resistance \\
\hline Iron & $54,56,57,58$ & $57 / 56$ & 0.586 & Poor \\
\hline Hafnium & $\begin{array}{l}174,176,177 \\
178,179,180\end{array}$ & $178 / 176$ & 0.172 & Good \\
\hline Osmium & $\begin{array}{c}184,186,187 \\
188,189,190 \\
192\end{array}$ & 190/192 & 0.713 & Poor \\
\hline Platinum & $\begin{array}{c}190,192,194 \\
195,196,198\end{array}$ & 196/195 & 0.368 & Good \\
\hline Titanium & $\begin{array}{c}46,47,48,49 \\
50\end{array}$ & $49 / 48$ & 0.583 & Good \\
\hline Tungsten & $\begin{array}{c}180,182,183 \\
184,186\end{array}$ & 184/182 & 0.032 & Fair \\
\hline
\end{tabular}

(a) Smaller numbers here indicate a greater change in the isotope ratio. Assuming there are no difficulties measuring these ratios, the smaller number implies a better indicator.

Review of the listed candidates for adequate corrosion resistance removed iron, osmium, and tungsten from consideration. Tungsten does, however, have the greatest change in isotope ratios and might be used in a tag if the tag were enclosed inside a clad tube. For the time being, we consider hafnium (Hf), titanium (Ti), and platinum (Pt) to be the most practical choices. Figures 1 through 7 show isotope ratio variations with burnup, using four different coolant densities. The highest density, $0.74 \mathrm{~g} / \mathrm{cc}$, is typical of pressurized water reactors (PWRs), Russian PWRs (VVERs), and BWRs low in the core, where void fraction is essentially zero.

The variation of the ${ }^{49} \mathrm{Ti} /{ }^{48} \mathrm{Ti}$ ratio with burnup is shown in Figure 1; it has been presented in previous technical reports. 


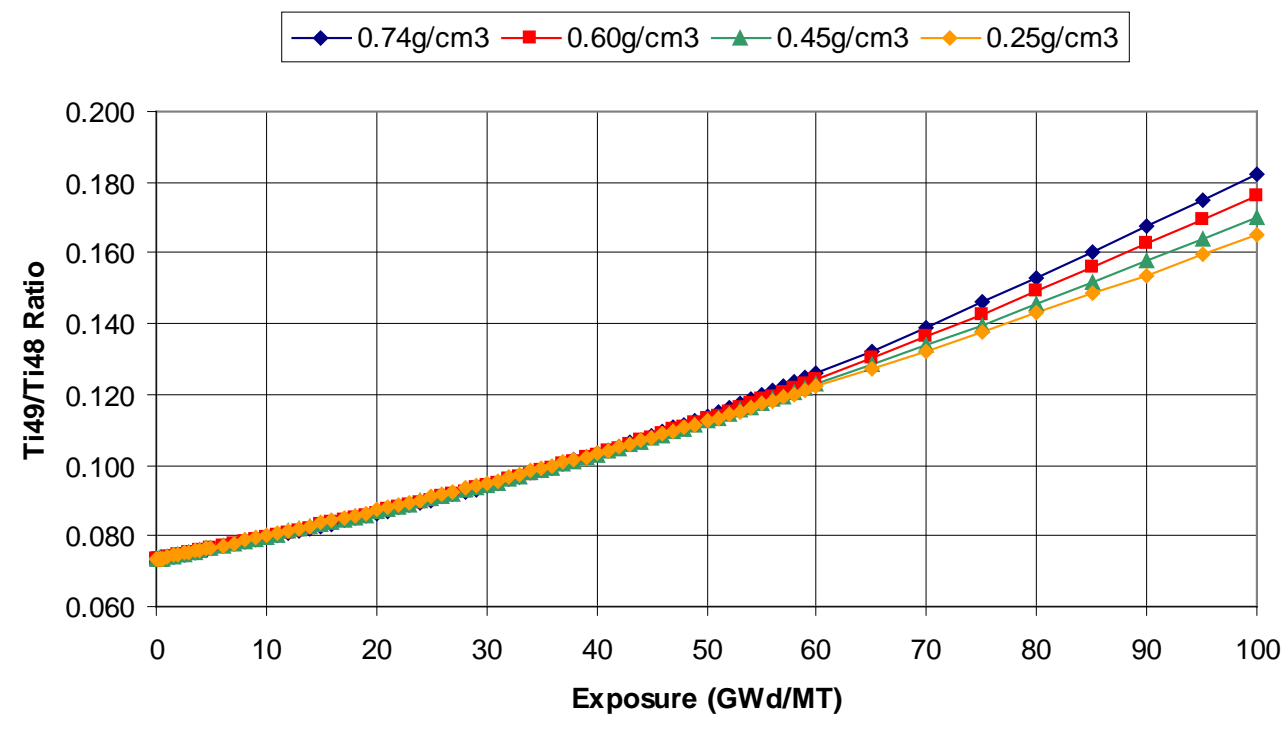

Figure 1. Calculated ${ }^{49} \mathrm{Ti} /{ }^{48} \mathrm{Ti}$ Ratios as a Function of Burnup

Hafnium has several natural stable isotopes and provides at least five potentially useful isotope ratios. Figures 2 through 6 show variation in specific hafnium isotope ratios over the normal commercial burnup of a fuel assembly.

As seen in Figure 2, the ratio of ${ }^{174} \mathrm{Hf}$ to ${ }^{176} \mathrm{Hf}$ declines steadily over the normal commercial operation of a fuel assembly. Note that the ratio itself is small because only $3 \%$ of natural hafnium is ${ }^{174} \mathrm{Hf}$; it decreases in abundance with irradiation. This ratio is not difficult to measure in the laboratory but may not be the first choice to measure with the portable SIMS machine at the reactor site.

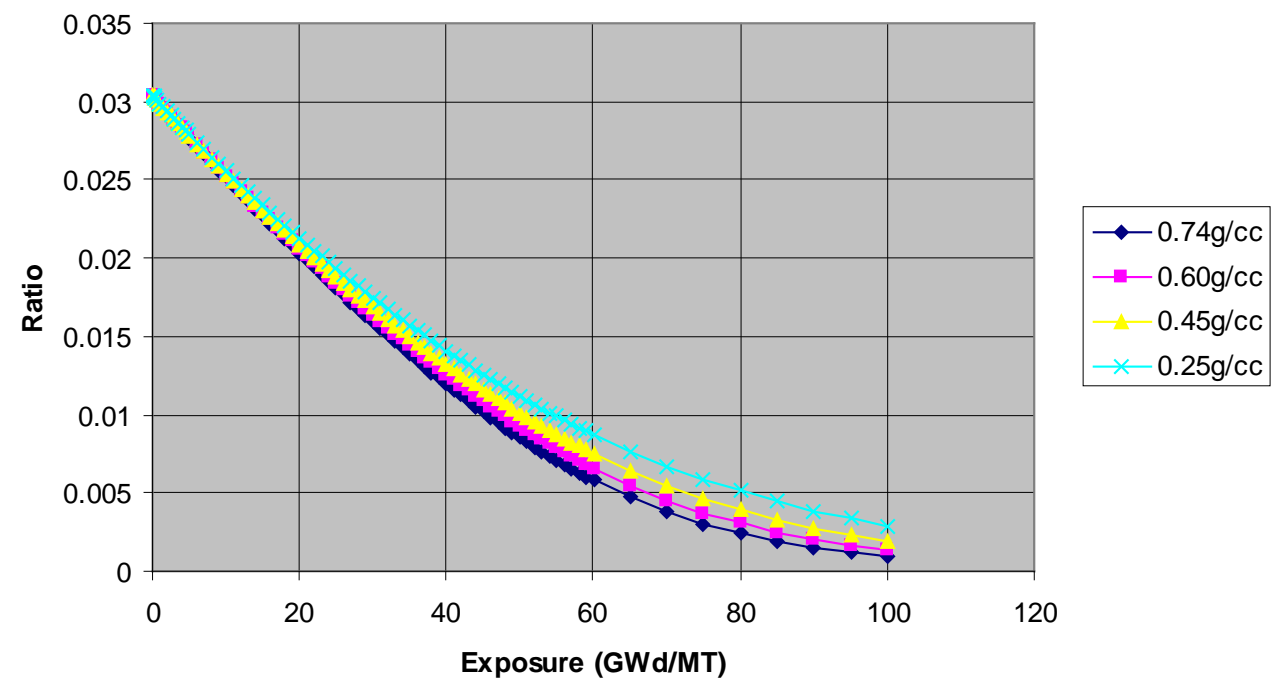

Figure 2. Calculated ${ }^{174} \mathrm{Hf} /{ }^{176} \mathrm{Hf}$ Ratios as a Function of Burnup 
The ratio of ${ }^{177} \mathrm{Hf}$ to ${ }^{176} \mathrm{Hf}$ declines sharply with increasing burnup; it is most useful below about $20 \mathrm{GWd} / \mathrm{MT}$.

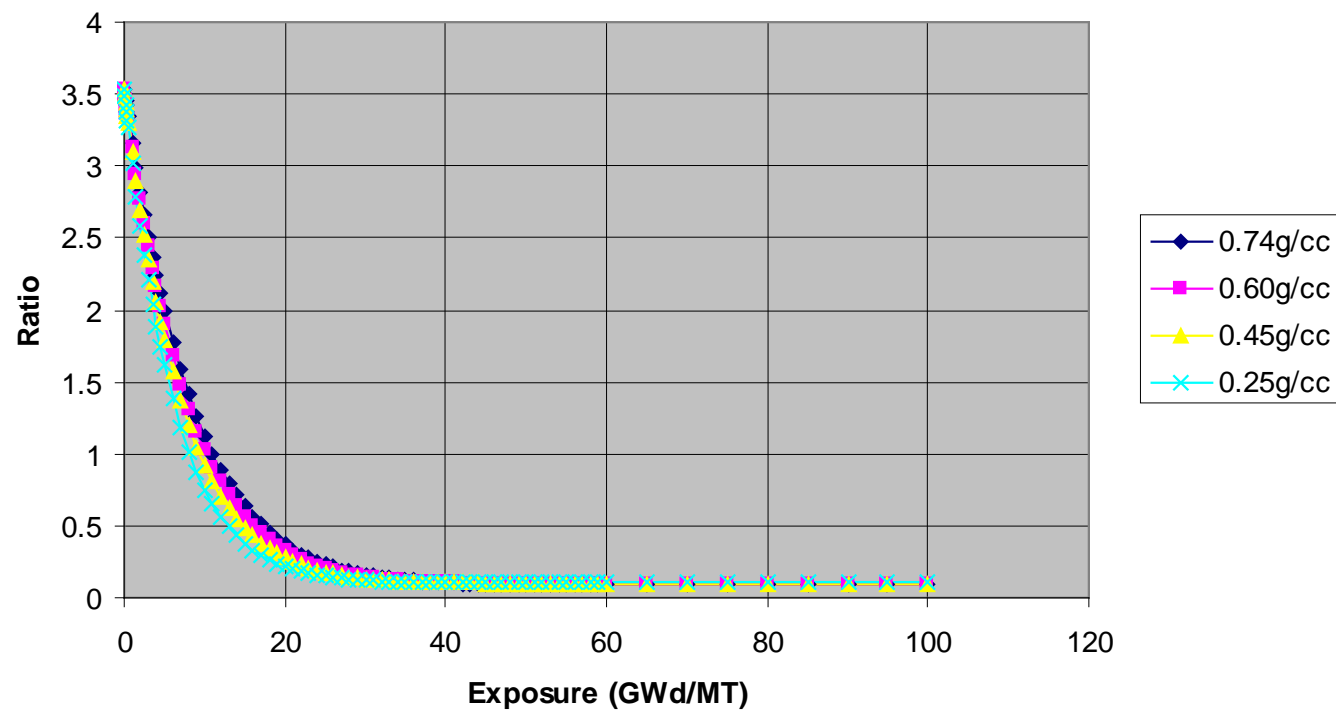

Figure 3. Calculated ${ }^{177} \mathrm{Hf}{ }^{176} \mathrm{Hf}$ Ratios as a Function of Burnup

The ratio of ${ }^{178} \mathrm{Hf}$ to ${ }^{176} \mathrm{Hf}$ initially peaks around $10 \mathrm{GWd} / \mathrm{MT}$, then declines over the normal commercial operation of a fuel assembly, as shown in Figure 4. This particular isotope ratio has a large difference between about $10 \mathrm{GWd} / \mathrm{MT}$ and the normal full-cycle operation of about $60 \mathrm{GWD} / \mathrm{MT}$.

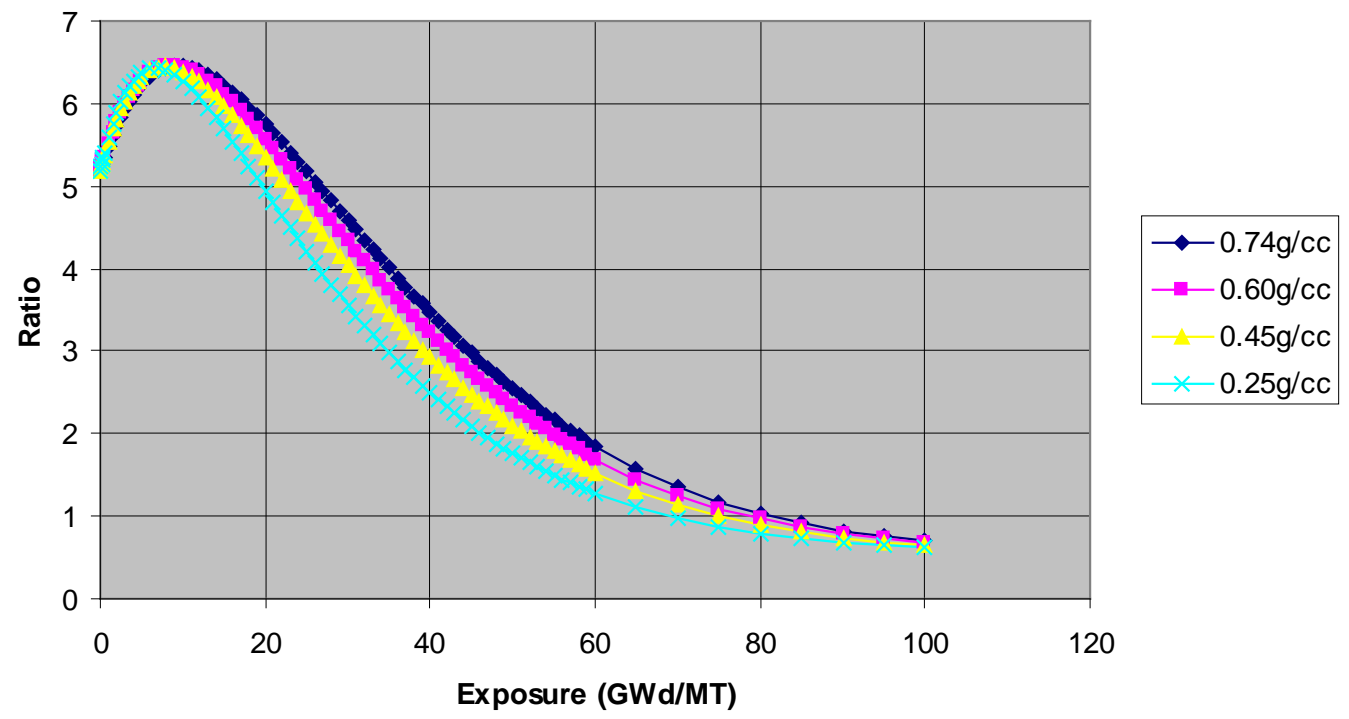

Figure 4. Calculated ${ }^{178} \mathrm{Hf} /{ }^{176} \mathrm{Hf}$ Ratios as a Function of Burnup 
The ratio of ${ }^{179} \mathrm{Hf}$ to ${ }^{176} \mathrm{Hf}$ increases steadily during normal commercial operation of a fuel assembly (Figure 5). This isotope ratio also varies strongly between about $10 \mathrm{GWd} / \mathrm{MT}$ and normal commercial end of assembly life.

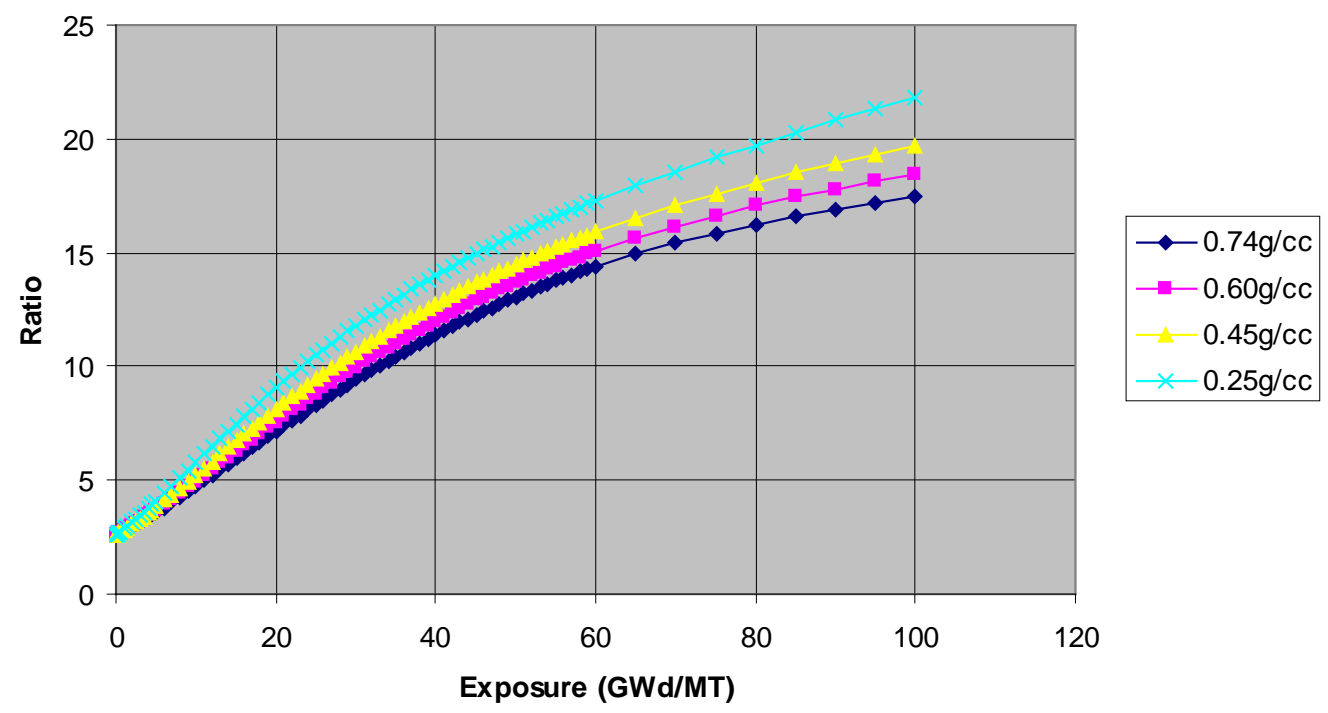

Figure 5. Calculated ${ }^{179} \mathrm{Hf} /{ }^{176} \mathrm{Hf}$ Ratios as a Function of Burnup

Figure 6 depicts the gradual increase in the ratio of ${ }^{180} \mathrm{Hf}$ to ${ }^{176}$ Hfover the normal commercial operation of a fuel assembly. This ratio changes more with lower moderator density, such as would be seen in a BWR.

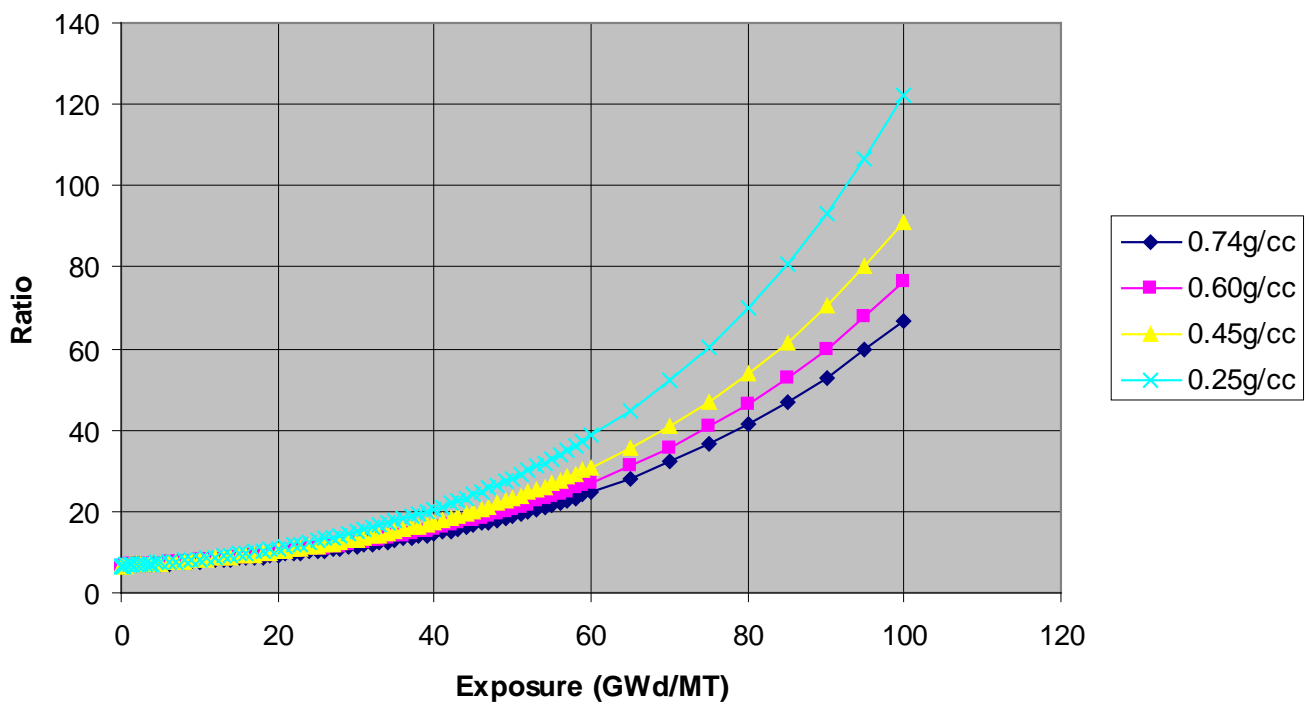

Figure 6. Calculated ${ }^{180} \mathrm{Hf} /{ }^{176} \mathrm{Hf}$ Ratios as a Function of Burnup 
The ratio of ${ }^{196} \mathrm{Pt}$ to ${ }^{195} \mathrm{Pt}$ increases steadily over the normal commercial operation of a fuel assembly, as shown in Figure 7.

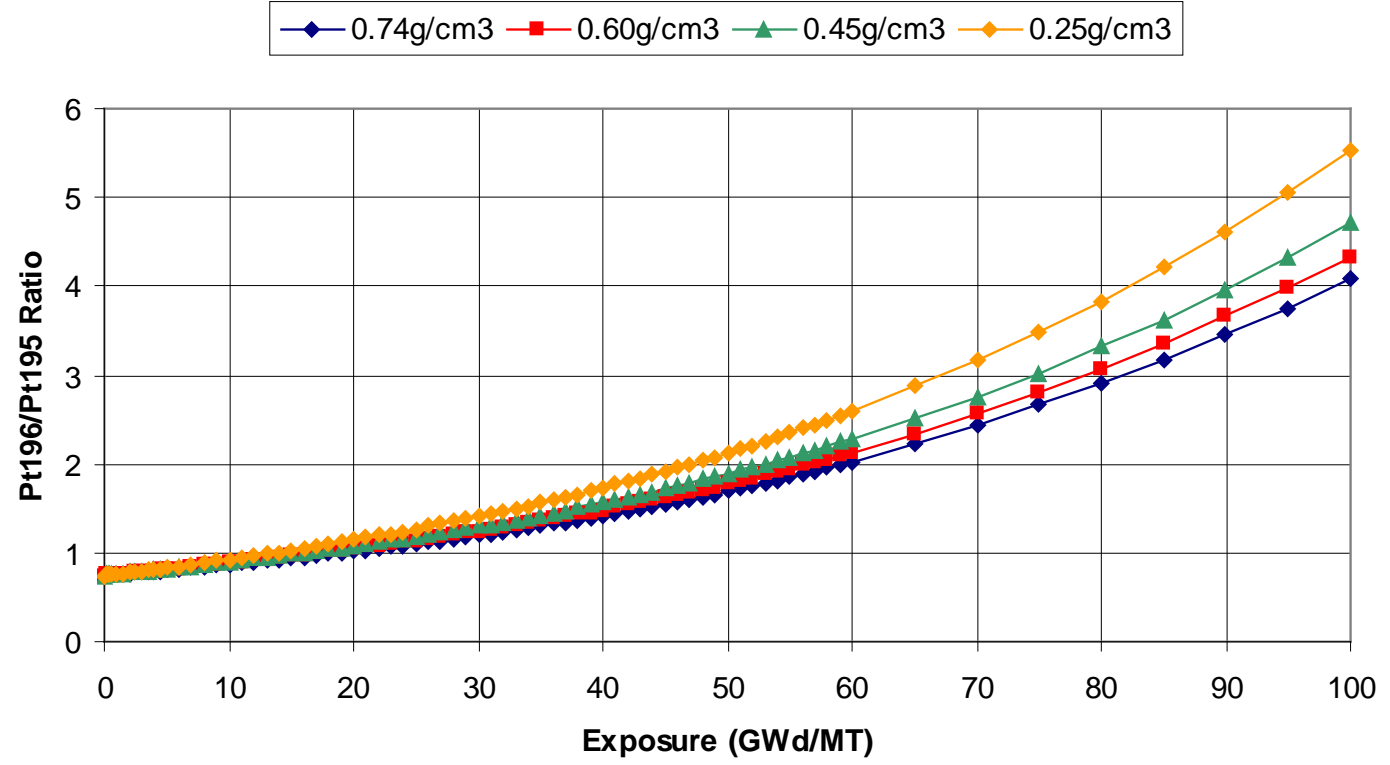

Figure 7. Calculated ${ }^{196} \mathrm{Pt} /{ }^{195} \mathrm{Pt}$ Ratios as a Function of Burnup

To date, the most practical form of a tag for use with typical light water reactor fuel assemblies appears to be either a wire or ribbon of metal. The wire or ribbon could be placed either in an unused guide or instrumentation tube or in a groove, machined specifically to accommodate the metal tag, on the outside of these tubes. 


\section{References}

Cliff JB, DP Frank, GJ Gesh, WW Little, Jr., GH Meriwether, RT Pagh, BD Reid, CW Becker, PA Simpson, and RE Touchberry. 2005. "Isotope Ratio Method Analysis of the Ford Nuclear Reactor." Presented to the Joint Meeting of the National Organization of Test, Research, and Training Reactors and the International Group on Research Reactors, September 12 - 16, 2005, Gaithersburg, Maryland. Available at http://www.ncnr.nist.gov/trtr2005/Proceedings/Gesh\%20-

\%20Isotope\%20Ratio\%20Method\%20FNR.pdf (October 2008).

Gerlach DC, JB Cliff, DE Hurley, BD Reid, WW Little, GH Meriwether, AJ Wickham, and TA Simmons. 2006. "Secondary ionization mass spectrometric analysis of impurity element isotope ratios in nuclear reactor materials.” Journal of Surface Science 252:7041-7044.

Gerlach DC, BD Reid, MR Mitchell, GJ Gesh, and DE Hurley. 2007. Determination of Light Water Reactor Fuel Burnup with the Isotope Ratio Method. PNNL-17053, Pacific Northwest National Laboratory, Richland, Washington.

Gesh CJ. 2004. A Graphite Isotope Ratio Method Primer: A Method for Estimating Plutonium Production in Graphite Moderated Reactors. PNNL-14568, Pacific Northwest National Laboratory, Richland, Washington.

Reid BD, DC Gerlach, and PG Heasler. 2001. Trawsfynydd Plutonium Estimate. PNNL-13528, Pacific Northwest National Laboratory, Richland, Washington. 



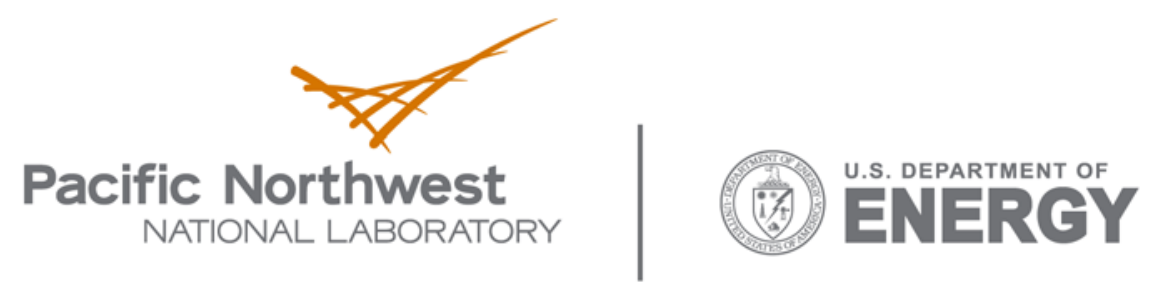

902 Battelle Boulevard

P.O. Box 999

Richland, WA 99352

1-888-375-PNNL (7665)

www.pnl.gov 